\title{
Volume-activated chloride channel exists in CD133+ lung cancer stem cells
}

$\mathrm{Z} \mathrm{MaO}^{1 *}, \mathrm{XXu^{2 }}$

From 23rd World Congress of the World Society of Cardio-Thoracic Surgeons

Split, Croatia. 12-15 September 2013

\section{Background}

The study is to research if volume-activated chloride channel (VACC) existed in tumor stem cells.

\section{Methods}

CD133+ cells were purified by magnetic cell separation (MACS) system from non-small cell lung cancer (NSCLC) cell line A549. The purity was detected by flow cytometry. VACC was recorded with whole-cell patch clamp.

\section{Results}

The purity of CD133+ cells isolated from A549 by MACS was $92.14 \%$. And VACC was recorded in the 22/ $40(55 \%)$ CD133+ cells of A549 by whole-cell patch clamp.

\section{Conclusion}

VACC exist in CD133+ lung cancer stem cells.

\section{Authors' details}

${ }^{1}$ Department of Thoracic Surgery, Renmin Hospital, Wuhan University, Wuhan, Hubei, China. ${ }^{2}$ Department of Pharmacology, Tongji Hospital, Huazhong University of Science and Technology, Wuhan, China.

Published: 11 September 2013

doi:10.1186/1749-8090-8-S1-P135

Cite this article as: Mao and Xu: Volume-activated chloride channel exists in CD133+ lung cancer stem cells. Journal of Cardiothoracic Surgery 2013 8(Suppl 1):P135

\footnotetext{
* Correspondence: gomzfogle@gmail.com

'Department of Thoracic Surgery, Renmin Hospital, Wuhan University, Wuhan, Hubei, China

Full list of author information is available at the end of the article
}

Submit your next manuscript to BioMed Central and take full advantage of:

- Convenient online submission

- Thorough peer review

- No space constraints or color figure charges

- Immediate publication on acceptance

- Inclusion in PubMed, CAS, Scopus and Google Scholar

- Research which is freely available for redistribution

Submit your manuscript at www.biomedcentral.com/submit 